\title{
Physicochemical properties of meat from Bos taurus and Bos indicus ${ }^{1}$
}

\author{
Maria Cristina Bressan², 3 , Erika Cristina Rodrigues², Lizandra Vercezi Rossato², Eduardo \\ Mendes Ramos ${ }^{2}$, Luis Telo da Gama ${ }^{3}$
}

\author{
1 Trabalho financiado pela CAPES, CNPq, FAPEMIG e FCT. \\ 2 Universidade Federal de Lavras, Departamento Ciência dos Alimentos - Lavras, MG - Brasil. \\ ${ }^{3}$ Estação Zootécnica Nacional - INRB, Fonte Boa, CP 2005-048, Vale de Santarém - Portugal.
}

\begin{abstract}
The objective of this study was to characterize meat quality in Bos taurus and Bos indicus and to determine the influence of finishing system and genetic group on the physicochemical properties of the longissimus thoracis at 24 hours and 10 days post mortem $\left(1^{\circ} \mathrm{C}\right)$. The sample included 160 bulls of the B. taurus $(n=75)$ and B. indicus ( $\left.\mathrm{n}=85\right)$ groups, finished either on pasture $(n=46)$ or with grain supplementation $(n=114)$, slaughtered at a carcass weight of 270 to $300 \mathrm{~kg}$. Pasturefinished animals had higher $\mathrm{pH}$, lower red content and a fat content 2.5 times lower than those finished with supplementation. Meat from supplement-finished animals had lower shear force in comparison to that from animals finished on pasture, with means of 7.7 and $8.5 \mathrm{~kg}$ at 24 hours, and of 5.5 and $5.9 \mathrm{~kg}$ at 10 days, respectively. Samples of B. taurus and B. indicus were similar in moisture and protein, but B. taurus presented higher means for ash and lower means for fat. Aged samples of $B$. indicus finished on pasture showed lower values for lightness and yellowness. Overall, lightness and yellow content increased and red content decreased with 10-day ageing. Means for shear force were lower in B. taurus than in B. indicus, with differences of $1.4 \mathrm{~kg}$ in fresh meat and $0.6 \mathrm{~kg}$ in aged samples. The reduction in shear force with ageing was more pronounced in samples with higher initial shear force, in spite of the positive relationship between shear force before and after ageing.
\end{abstract}

Key Words: beef, finishing system, genetic group, meat quality

\section{Propriedades físico-químicas de carnes de Bos taurus e Bos indicus}

RESUMO - Este estudo foi conduzido com os objetivos de caracterizar a qualidade de carnes de Bos taurus e Bos indicus e determinar a influência do sistema de terminação e dos grupos genéticos nas propriedades físico-químicas do músculo longissimus thoracis às 24 horas e aos 10 dias post mortem $\left(1^{\circ} \mathrm{C}\right)$. Na amostragem foram usados 160 bovinos $B$. taurus ( $\mathrm{n}=75$ ) e B. indicus $(n=85)$ terminados a pasto $(n=46)$ ou com suplementação de grãos $(n=114)$, abatidos com peso de carcaça entre 270 a $300 \mathrm{~kg}$. O teor de gordura foi 2,5 vezes mais baixo em animais terminados a pasto. A carne dos animais terminados com suplementação apresentou pH mais baixo, com maior teor de vermelho, e força de cisalhamento mais baixa em comparação à dos animais terminados a pasto, com médias de 7,7 e 8,5 kg (24 horas) e 5,5 e 5,9 kg (10 dias), respectivamente. Amostras de $B$. taurus e $B$. indicus foram similares em umidade e proteína, porém as de $B$. taurus mostraram média mais alta de cinzas e mais baixas de gordura. Amostras maturadas de B. indicus terminados a pasto mostraram valores mais baixos de luminosidade e índice de amarelo. Em geral, a luminosidade e o teor de amarelo aumentaram e o teor de vermelho diminuiu com a maturação de dez dias. As médias de força de cisalhamento foram mais baixas em $B$. taurus que em B. indicus, com diferenças de $1,4 \mathrm{~kg}$ na carne fresca e $0,6 \mathrm{~kg}$ em amostras maturadas. A redução na força de cisalhamento com a maturação é mais pronunciada em amostras com alta força de cisalhamento inicial, apesar da relação positiva com a força de cisalhamento antes e após a maturação.

Palavras-chave: bovinos, grupo genético, qualidade de carne, sistema de terminação

\section{Introduction}

With nearly 170 million cattle, Brazil is the second largest beef producing country in the world and has been the leading exporter of beef over the last few years (USDA, 2007). Beef production systems in Brazil are extremely diversified. In northern Brazil the climate is predominantly tropical and subtropical and $B$. indicus breeds are used extensively there whereas in the south, the climate is cooler, and cattle production is based on B. taurus breeds. Overall, it is estimated that nearly $83 \%$ of beef production in Brazil is from Zebu breeds and their crosses (Mariante et al., 2003). Finishing of commercial beef cattle usually takes place in pasture, but feedlot 
finishing is also adopted for a period of about 3 months (Lopes \& Magalhães, 2005).

The diversity of production conditions and genetic background in Brazilian commercial beef cattle is expected to result in considerable variability in beef quality, as it is known that both finishing system and genotype will influence meat quality. Several studies have shown that, when compared with $B$. taurus breeds, meat from B. indicus has reduced tenderness (Wheeler et al., 2001), presumably due to increased post mortem activity of calpastatin (Shackelford et al., 1991; O’Connor et al., 1997), but studies on the effects of zebu inheritance on meat color have shown inconsistent results (Silveira et al., 2006). When compared with pasture-based systems, supplementfinishing results in meat with higher fat content (French et al., 2001) and lighter color (Bruce et al., 2004), but the influence on meat tenderness is not clear (Realini et al., 2004).

The objectives of this work were to characterize meat quality in commercial beef cattle in Brazil by analyzing the physicochemical characteristics of the longissimus thoracis in a sample of animals processed by the packing industry, and to assess the influences of finishing system and genetic group on beef quality attributes.

\section{Material and Methods}

In this work, M. longissimus thoracis (LT) samples were collected from 160 commercial bulls, at 26 to 40 months of age (corresponding to the typical age range for commercial beef cattle in Brazil), with carcass weight ranging from 270 to $300 \mathrm{~kg}$, slaughtered in a processing plant certified for beef exporting.

Sampling was carried out in an attempt to represent the range of genotypes and production conditions typically observed in Brazil, and included animals of the genetic groups $B$. taurus $(\mathrm{n}=75)$ and $B$. indicus $(\mathrm{n}=85)$, which were classified as having been finished either on pasture (FP) or with grain supplementation (FG). In FP ( $\mathrm{n}=46$, of which 20 were $B$. taurus and 26 were $B$. indicus), animals were raised on grass (Brachiaria brizantha cv. Marandu, Brachiaria decumbens, Brachiaria humidicula and Panicum maximum Jacq.) in the Brazilian state of Minas Gerais, whereas in FG ( $\mathrm{n}=114$, of which 55 were B. taurus and 59 B. indicus) a finishing period of about 90 days was adopted, when animals were supplemented with about 50\% roughage (chopped sugar cane) and $50 \%$ concentrate (consisting of $40.5 \%$ corn, $6 \%$ soybean meal, $1.5 \%$ urea and $2 \%$ minerals and vitamins).

Animals were slaughtered humanely after 14 hours of fasting, according to official procedures, with electrical stimulation of the carcass. Carcasses were chilled at $0^{\circ} \mathrm{C}$, and cold-boned at 24 hours post mortem. At this time, a sample of the LT with approximately $500 \mathrm{~g}$ was collected between the 5th and the 7th rib of the carcass left side, individually vacuum-packaged, frozen at $-30^{\circ} \mathrm{C}$ to $-35^{\circ} \mathrm{C}$, and stored at $-20^{\circ} \mathrm{C}$ until further analyses.

Meat $\mathrm{pH}$ at 24 hours was measured by making a scalpel incision in the LT between the 12th and 13th rib, and inserting a glass electrode attached to a portable $\mathrm{pH}$ meter M 1120× (Mettler-Toledo International Inc., Columbus, EUA), approximately $2.5 \mathrm{~cm}$ into the muscle. From each point, three $\mathrm{pH}$ measurements were taken, and the mean of these measurements was used for statistical analyses.

After approximately 30 days of frozen storage, samples were thawed at $4^{\circ} \mathrm{C}$ for $24 \mathrm{~h}$, trimmed of subcutaneous fat and connective tissue in the surface and separated into two different portions, which were either immediately analyzed or submitted to ageing for 10 days at $1^{\circ} \mathrm{C}$. From both fresh and aged samples, three slices with a thickness of $15 \mathrm{~mm}$ were obtained by sectioning the LT perpendicular to the muscle fibers. After 30 minutes of blooming at $4^{\circ} \mathrm{C}$, a colorimeter Cr-400 (Minolta Camera Co., Ltd., Osaka, Japan) and the D65 illuminant were used to measure lightness ( $\left.\mathrm{L}^{*}\right)$, redness ( $\mathrm{a}^{*}$ ) and yellowness (b*) of the surface of the LT slice, according to the CIE color scores. From each steak, three color measurements were obtained, and the mean of the nine measurements per animal was used for further analyses. The $\mathrm{L}^{*}, \mathrm{a}^{*}$ and $\mathrm{b} *$ color coordinates were obtained in both fresh (24 hours post mortem) and aged (10 days post mortem) meat samples.

Cooking loss was estimated in fresh (24 hours post mortem) and aged (10 days post mortem) meat, according to the procedures recommended by AMSA (1978). Briefly, steaks were weighed and then grilled in aluminum foil at $150^{\circ} \mathrm{C}$, until reaching an internal temperature of $65^{\circ} \mathrm{C}$. After cooling, steaks were weighed again, and the difference in weight before and after broiling, expressed as a percentage of initial weight, was considered to correspond to cooking loss. The three measurements obtained per carcass-ageing time combination were averaged for further analyses.

Meat tenderness was evaluated by using peak Warner-Bratzler shear force, in both fresh (24 hours post mortem) and aged (10 days post mortem) meat. From each cooked steak, three cores $(1 \times 1 \mathrm{~cm})$ were cut parallel to the direction of the muscle fibers, and sheared by using a texturometerTA-XT2(Stable Micro System, Surrey, England), equipped with a Warner-Bratzler shearing device, with a layer of $1.016 \mathrm{~mm}$ (pre-test speed $1.00 \mathrm{~mm} / \mathrm{s}$, post-test speed $5.00 \mathrm{~mm} / \mathrm{s}$, distance $25.00 \mathrm{~mm}$ ). Results were expressed 
in $\mathrm{kg}$, and the mean of nine measurements (three slices with three replicates per slice) per carcass-ageing time combination was used for statistical analyses.

Samples of fresh and aged meat were minced in a commercial mixer-blender until a homogeneous mass was obtained, and chemical analyses were carried out in duplicate. Crude protein was estimated by the method of Kjeldahl and fat by Soxhlet (AOAC, 1995). Moisture was determined in an oven at $105^{\circ} \mathrm{C}$ until a constant weight was reached, and ash concentration was determined on the residue of samples after drying for $12 \mathrm{~h}$ at $550^{\circ} \mathrm{C}$. For cholesterol determination, fat was extracted from LT samples as described by Folch et al. (1957), and cholesterol was quantified by colorimetry, with a modification of the method of Bohac et al. (1988), as described by Bragagnolo \& Rodriguez-Amaya (2001). All chemical components were expressed as percentages of the meat sample, except for cholesterol, which was expressed in mg/100 g of meat.

Before carrying out statistical analyses, changes in meat quality with ageing for 10 days were computed per animal, by calculating the differences between samples before and after ageing, for the $\mathrm{L}^{*}, \mathrm{a}^{*}$ and $\mathrm{b}^{*}$ color coordinates $\left(\mathrm{L}_{\mathrm{d}}, \mathrm{a}_{\mathrm{d}}\right.$ and $\mathrm{b}_{\mathrm{d}}$, respectively), for cooking loss $\left(\mathrm{CL}_{\mathrm{d}}\right)$ and for shear force $\left(\mathrm{SF}_{\mathrm{d}}\right)$.

The data were considered to have originated from a factorial design with two genetic groups and two finishing systems, and the GLM procedure of SAS (SAS Institute, 2004) was used in analyses of variance to study the effects of finishing system, genetic group and their interaction, on the response variables evaluated, i.e., color coordinates, cooking loss and shear force, all measured in fresh and aged meat, as well as changes in these variables with ageing. The same linear model was used in the analysis of $\mathrm{pH}$, crude protein, fat, moisture, ash and cholesterol. If the interaction was not significant $(\mathrm{P}>0.05)$, it was dropped from the model, and the data re-analyzed with a model including only the main effects of genetic group and finishing system. Correlations among variables were estimated with the CORR procedure of SAS (SAS, 2004), both for the full data set and within finishing system, to assess the relationship among the variables studied. Differences among correlation coefficients estimated by finishing system were tested by using Fisher Z-transformation (Snedecor \& Cochran, 1989).

Table 1 - Descriptive statistics, statistical significance of factors considered in the analyses of variance of physicochemical characteristics of muscle longissimus thoracis in beef cattle

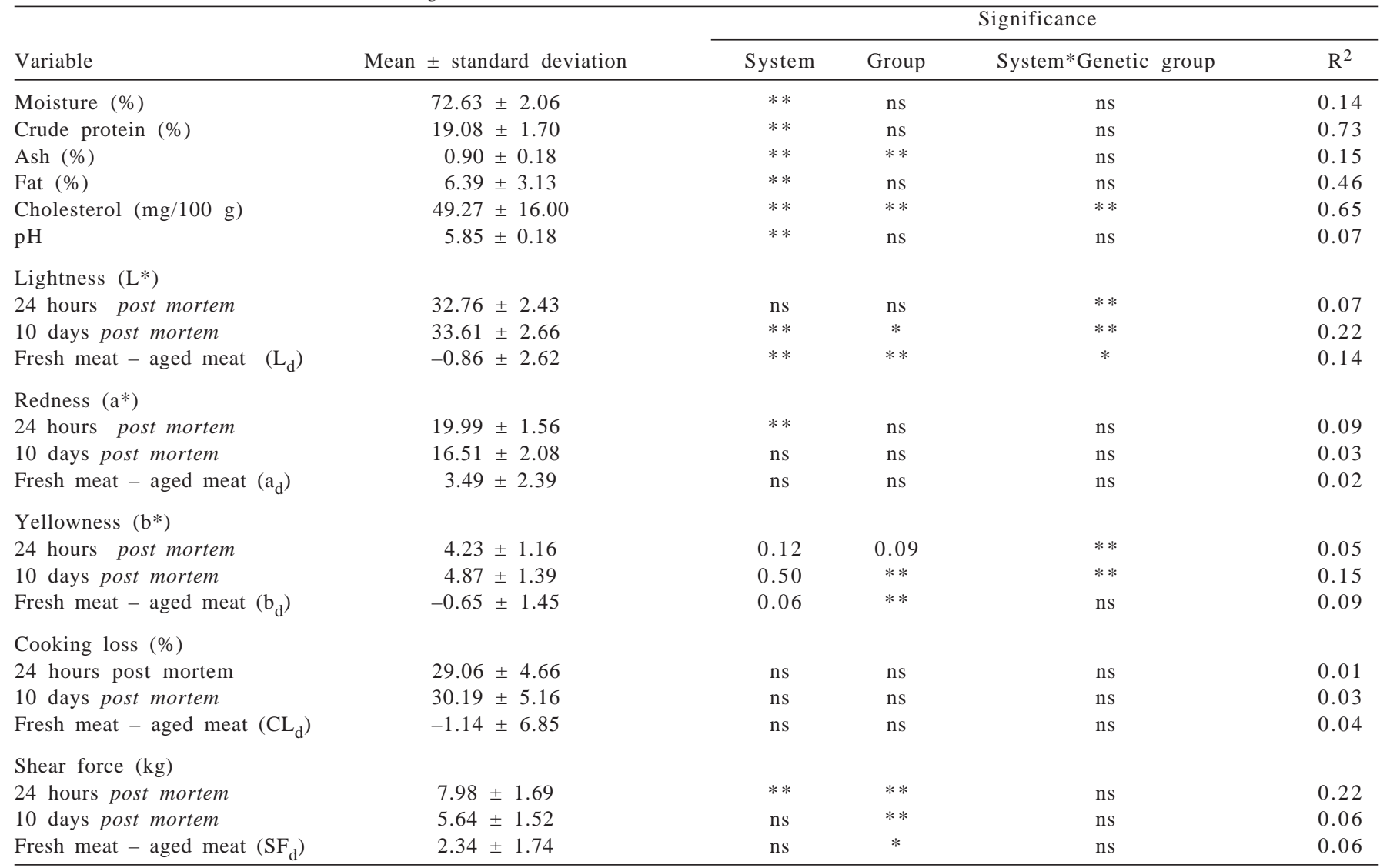

** Significant at the $1 \%$ level $(\mathrm{P}<0.01)$, *Significant at the $5 \%$ level $(\mathrm{P}<0.05)$; ns = non-significant $(\mathrm{P}>0.05)$. 


\section{Results and Discussion}

With the exception of crude protein, fat, cholesterol, 10- day L* and 24-hour shear force, the factors considered in the statistical model explained only less than $20 \%$ of the variability observed (Table 1), as it would be expected in a study conducted with commercial beef cattle, given the high variability among individuals. Nevertheless, for crude protein, fat and cholesterol, the coefficient of determination ranged between 46 and $73 \%$.

The interaction between genetic group and finishing system was significant $(\mathrm{P}<0.05)$ for cholesterol, 24 hour- $\mathrm{L}^{*}$, 10 day- $L^{*}, L_{d}$, 24 hour-b* and 10-day b*, but not for the other variables. The finishing system affected significantly $(\mathrm{P}<0.05)$ moisture, crude protein, fat, ash, cholesterol, $\mathrm{pH}$, 10-day L*, $\mathrm{L}_{\mathrm{d}}, 24$-hour a*, and 24-hour shear force, whereas the genetic group had a significant influence $(\mathrm{P}<0.05)$ on ash, cholesterol, 10-dayL*, $\mathrm{L}_{\mathrm{d}}, 10$-day b* , $\mathrm{b}_{\mathrm{d}}$, 24- hour shear force, and 10-day shear force.

Depending on the significance of the interaction, the least squares means for the different variables are presented for combinations of finishing system with genetic group, or individually by finishing system and by genetic group (Table 2).

When compared with FG (Table 2), samples from FP animals had higher moisture, crude protein and ash which were higher by $1.60 \%, 3.20 \%$ and $0.10 \%$, respectively ( $\mathrm{P}<0.01)$, but crude fat was $4.70 \%$ lower $(\mathrm{P}<0.01)$. Finishing system affected significantly the $\mathrm{pH}$ of meat $(\mathrm{P}<0.01)$, with an average $\mathrm{pH}$ which was 0.10 units lower in FG animals.

Redness of fresh meat from FP animals was lower by 1.00 units when compared with $\mathrm{FG}(\mathrm{P}<0.05)$, whereas in aged meat redness was similar $(\mathrm{P}>0.05)$ for the two finishing systems (Table 2). Redness dropped significantly $(\mathrm{P}<0.01)$

Table 2 - Physicochemical characteristics of M. longissimus thoracis of beef cattle, by finishing system, genetic group and for combinations of finishing system and genetic group

\begin{tabular}{|c|c|c|c|c|c|c|c|c|}
\hline \multirow[b]{3}{*}{ Variable $^{2}$} & \multirow{2}{*}{\multicolumn{2}{|c|}{ Finishing system }} & \multirow{2}{*}{\multicolumn{2}{|c|}{ Genetic group }} & \multicolumn{4}{|c|}{ Finishing system $*$ genetic group } \\
\hline & & & & & \multicolumn{2}{|c|}{ Pasture } & \multicolumn{2}{|c|}{ Grain } \\
\hline & Pasture & Grain & Taurus & Indicus & Taurus & Indicus & Taurus & Indicus \\
\hline Moisture (\%) & $73.8 \pm 0.28 a$ & $72.2 \pm 0.18 b$ & $73.3 \pm 0.24$ & $72.7 \pm 0.22$ & - & - & - & - \\
\hline Crude protein (\%) & $21.4 \pm 0.13 a$ & $18.2 \pm 0.08 b$ & $19.7 \pm 0.11$ & $19.8 \pm 0.10$ & - & - & - & - \\
\hline Ash (\%) & $0.97 \pm 0.03 a$ & $0.87 \pm 0.02 b$ & $0.97 \pm 0.02 \mathrm{a}$ & $0.87 \pm 0.02 b$ & - & - & - & - \\
\hline Fat $(\%)$ & $3.0 \pm 0.34 a$ & $7.7 \pm 0.22 b$ & $5.0 \pm 0.28 a$ & $5.7 \pm 0.26 b$ & - & - & - & - \\
\hline Cholesterol (mg/100 g) & - & - & - & - & $45.5 \pm 2.15 a$ & $36.9 \pm 1.88 \mathrm{~b}$ & $38.8 \pm 1.30 \mathrm{~b}$ & $65.8 \pm 1.25 c$ \\
\hline $\mathrm{pH}$ & $5.92 \pm 0.03 a$ & $5.82 \pm 0.02 b$ & $5.86 \pm 0.02$ & $5.87 \pm 0.02$ & - & - & - & - \\
\hline \multicolumn{9}{|l|}{ Lightness (L*) } \\
\hline 24 hours post mortem & - & - & - & - & $33.0 \pm 0.53 \mathrm{ab}$ & $32.3 \pm 0.47 a$ & $32.1 \pm 0.32 \mathrm{a}$ & $33.5 \pm 0.31 b$ \\
\hline 10 days post mortem & - & - & - & - & $33.9 \pm 0.53 \mathrm{ab}$ & $30.9 \pm 0.46 c$ & $33.7 \pm 0.32 \mathrm{a}$ & $34.7 \pm 0.31 b$ \\
\hline Fresh meat - aged meat $\left(\mathrm{L}_{\mathrm{d}}\right)$ & - & - & - & - & $-0.9 \pm 0.55 a$ & $1.3 \pm 0.48 b$ & $-1.6 \pm 0.33 a$ & $-1.15 \pm 0.32 \mathrm{a}$ \\
\hline Significance of $\mathrm{L}_{\mathrm{d}}$ & - & - & - & - & ns & $* *$ & $* *$ & $* *$ \\
\hline \multicolumn{9}{|l|}{ Redness $\left(\mathrm{a}^{*}\right)$} \\
\hline 24 hours post mortem & $19.3 \pm 0.22 \mathrm{a}$ & $20.3 \pm 0.14 b$ & $19.8 \pm 0.18$ & $19.8 \pm 0.17$ & - & - & - & - \\
\hline 10 days post mortem & $16.1 \pm 0.31 \mathrm{a}$ & $16.7 \pm 0.19 a$ & $16.5 \pm 0.25$ & $16.3 \pm 0.24$ & - & - & - & - \\
\hline Fresh meat - aged meat $\left(a_{d}\right)$ & $3.2 \pm 0.35 a$ & $3.6 \pm 0.22 \mathrm{a}$ & $3.4 \pm 0.29$ & $3.5 \pm 0.27$ & - & - & - & - \\
\hline Significance of $a_{d}$ & $* *$ & $* *$ & $* *$ & $* *$ & - & - & - & - \\
\hline \multicolumn{9}{|l|}{ Yellowness (b*) } \\
\hline 24 hours post mortem & - & - & - & - & $4.9 \pm 0.26 a$ & $4.0 \pm 0.22 b$ & $4.1 \pm 0.15 b$ & $4.2 \pm 0.15 b$ \\
\hline 10 days post mortem & - & - & - & - & $5.7 \pm 0.29 a$ & $3.9 \pm 0.26 b$ & $5.2 \pm 0.18 \mathrm{a}$ & $4.7 \pm 0.17 \mathrm{c}$ \\
\hline Fresh meat - aged meat $\left(b_{d}\right)$ & $-0.33 \pm 0.21 \mathrm{a}$ & $-0.81 \pm 0.13 b$ & $-0.94 \pm 0.17 a$ & $-0.19 \pm 0.16 b$ & - & - & - & - \\
\hline Significance of $b_{d}$ & ns & $* *$ & $* *$ & ns & - & - & - & - \\
\hline \multicolumn{9}{|l|}{ Cooking loss (\%) } \\
\hline 24 hours post mortem & $29.9 \pm 0.69$ & $28.7 \pm 0.44$ & $29.3 \pm 0.57$ & $29.3 \pm 0.53$ & - & - & - & - \\
\hline 10 days post mortem & $29.3 \pm 0.76$ & $30.5 \pm 0.48$ & $29.8 \pm 0.63$ & $30.0 \pm 0.59$ & - & - & - & - \\
\hline Fresh meat - aged meat $\left(\mathrm{CL}_{\mathrm{d}}\right)$ & $0.59 \pm 1.00 \mathrm{a}$ & $-1.82 \pm 0.64 b$ & $-0.50 \pm 0.83$ & $-0.73 \pm 0.77$ & - & - & - & - \\
\hline Significance of $\mathrm{CL}_{\mathrm{d}}$ & ns & $* *$ & ns & ns & - & - & - & - \\
\hline \multicolumn{9}{|l|}{ Shear force (kg) } \\
\hline 24 hours post mortem & $8.5 \pm 0.22 a$ & $7.7 \pm 0.14 b$ & $7.4 \pm 0.18 a$ & $8.8 \pm 0.17 b$ & - & - & - & - \\
\hline 10 days post mortem & $5.9 \pm 0.22 \mathrm{a}$ & $5.5 \pm 0.14 b$ & $5.4 \pm 0.18 a$ & $6.0 \pm 0.17 b$ & - & - & - & - \\
\hline Fresh meat - aged meat $\left(\mathrm{SF}_{\mathrm{d}}\right)$ & $2.6 \pm 0.25 a$ & $2.2 \pm 0.16 a$ & $2.0 \pm 0.21 \mathrm{a}$ & $2.7 \pm 0.19 b$ & - & - & - & - \\
\hline Significance of $\mathrm{SF}_{\mathrm{d}}$ & $* *$ & $* *$ & $* *$ & $* *$ & - & - & - & - \\
\hline
\end{tabular}

** Significant at the $1 \%$ level $(\mathrm{P}<0.01)$, Significant at the $5 \%$ level $(\mathrm{P}<0.05)$; ns = non-significant $(\mathrm{P}>0.05)$.

${ }^{1}$ For a given factor or combination of factors, means without a common letter differ $(\mathrm{P}<0.05)$ by Tukey test. 
with ageing $\left(\mathrm{a}_{\mathrm{d}}\right)$, by a similar amount in the two finishing systems $(\mathrm{P}>0.05)$. Differences among finishing systems in meat lightness and yellowness depended on the genetic group considered, both in fresh and aged meat. Yellowness increased with ageing in $\mathrm{FG}$ animals $(\mathrm{P}<0.01)$, but changes were minor in $\mathrm{FP}(\mathrm{P}>0.05)$ whereas the changes in lightness $\left(\mathrm{L}_{\mathrm{d}}\right)$ with finishing system depended on genetic group.

Cooking loss in fresh and aged meat was similar $(\mathrm{P}>0.05)$ for the two finishing systems (Table 2), but the ageing process resulted in a significant $(\mathrm{P}<0.01)$ drop $\left(\mathrm{CL}_{\mathrm{d}}\right)$ in FG samples whereas no significant changes occurred with ageing in FP samples ( $\mathrm{P}>0.05)$.

The shear force in fresh and aged meat was significantly $(\mathrm{P}<0.05)$ higher in FP samples, with a difference of 0.80 and $0.40 \mathrm{~kg}$, respectively, when compared with FG samples. The ageing process resulted in a significant $(\mathrm{P}<0.01)$ decrease in shear force, of $2.60 \mathrm{~kg}$ in FP and $2.20 \mathrm{~kg}$ in FG, which did not differ from each other $(\mathrm{P}>0.05)$.

B. taurus and B. indicus groups did not differ $(\mathrm{P}>0.05)$ in meat moisture, crude protein content, $\mathrm{pH}$, as well as in redness and cooking loss, both in fresh and aged meat. On the other hand, differences between B. taurus and B. indicus were found in ash, fat, $b_{d}$, 24-hour shear force, 10-day shear force and $\mathrm{SF}_{\mathrm{d}}$, whereas differences between genetic groups in cholesterol, 24-hour L*, 10-day L*, $\mathrm{L}_{\mathrm{d}}$, 24-hour b* and 10 day-b* depended on the finishing system.

The amount of ash (Table 2) was higher in B. taurus by $0.1 \%$ whereas the mean fat was $0.70 \%$ higher $(\mathrm{P}<0.05)$ in $B$. indicus. The increase in yellowness with meat ageing $\left(\mathrm{b}_{\mathrm{d}}\right)$ was higher by 0.75 units in $B$. taurus when compared with B. indicus $(\mathrm{P}<0.05)$.

The shear force was lower $(\mathrm{P}<0.01)$ in $B$. taurus than in $B$. indicus, by $1.40 \mathrm{~kg}$ in fresh and by $0.60 \mathrm{~kg}$ in aged samples. Shear force declined with ageing in both genetic groups $(\mathrm{P}<0.01)$, but $\mathrm{SF}_{\mathrm{d}}$ differed between them $(\mathrm{P}<0.05)$, with a mean $\mathrm{SF}_{\mathrm{d}}$ of $2.00 \mathrm{~kg}$ in B. taurus, and $2.70 \mathrm{~kg}$ in B. indicus.

Meat lightness in samples of FG animals was higher in $B$. indicus by 1.40 units in fresh meat and 1.00 units in aged meat $(\mathrm{P}<0.05)$. However, lightness was similar in fresh meat from both genetic groups in FP animals $(\mathrm{P}>0.05)$ whereas in aged meat lightness was higher by 3.00 units in $B$. taurus $(\mathrm{P}<0.05)$. Overall, lightness increased with ageing in both genetic groups in $\mathrm{FG}(\mathrm{P}<0.01)$, but in $\mathrm{FP}$ a decline in lightness was observed in $B$. indicus samples, and no significant changes were observed in $B$. taurus $(\mathrm{P}>0.05)$.

Yellowness of fresh and aged meat was higher $(\mathrm{P}<0.05)$ in B. taurus than in B. indicus in FP, by 0.90 and 1.80 points, respectively. In FG, 24-hour $\mathrm{b}^{*}$ was similar for the two genetic groups ( $\mathrm{P}>0.05)$, but 10-day $\mathrm{b} *$ was higher by 0.50 units in $B$. taurus $(\mathrm{P}<0.05)$.

The differences among genetic groups in cholesterol content were highly dependent on the finishing system considered, with higher cholesterol levels in B. taurus under pasture-finishing (about $8.60 \mathrm{mg}, \mathrm{P}<0.05$ ), but much higher for $B$. indicus in the FG system (about $27 \mathrm{mg}, \mathrm{P}<0.05$ ).

The samples of LT muscle from $B$. taurus and $B$. indicus animals, finished on pasture or with grain supplementation, showed changes in color $\mathrm{L}^{*}, \mathrm{a}^{*}$ and $\mathrm{b}^{*}$ coordinates, when subject to an ageing process of 10 days at $1^{\circ} \mathrm{C}$. In FG animals, meat became lighter with ageing (Table 2), whereas in $\mathrm{FP}$, ageing resulted in darker meat in $B$. indicus but no changes $(\mathrm{P}>0.05)$ were observed in $B$. taurus animals. Ageing of meat also resulted in a decrease in redness $(\mathrm{P}<0.01)$, which was similar in both finishing systems and genetic groups $(\mathrm{P}>0.05)$. On the other hand, yellowness increased with ageing in $B$. taurus and $F G(P<0.01)$ whereas changes were minor in FP and in B. indicus $(\mathrm{P}>0.05)$.

Cooking loss increased with ageing in FG animals $(\mathrm{P}<0.01)$, but no significant changes were observed in FP $(\mathrm{P}>0.05)$. When analyzed by genetic group, cooking loss did not change with ageing $(\mathrm{P}>0.05)$ in neither of them.

Meat tenderness improved substantially with ageing $(\mathrm{P}<0.01)$ by a similar amount in the two finishing systems $(\mathrm{P}>0.05)$. The decrease in shear force with ageing was observed in the two genetic groups $(\mathrm{P}<0.01)$, but it was higher in B. indicus when compared to B. taurus $(\mathrm{P}<0.05)$.

The relationship of 24-hour shear force with 10-day shear force and $\mathrm{SF}_{\mathrm{d}}$ (Figure 1) indicates that meat with higher 24-hour shear force tended to also have higher 10-day shear force $(r=0.417 ; \mathrm{P}<0.01)$, even though the improvement in meat tenderness with the ageing process was higher as shear force increased in fresh meat $(\mathrm{r}=0.609 ; \mathrm{P}<0.01)$. This is in line with the finding that the $B$. indicus group, which had the highest 24-hour shear force, benefited more from ageing in terms of meat tenderness, although the 10-day shear force was still higher in $B$. indicus, but with a much lower difference from $B$. taurus than what was observed for 24-hour shear force.

The correlation coefficients (Table 3) indicate that the stronger relationships were found among variables in the same category, i.e., among color coordinates, physical variables and chemical components, whereas the relationships among variables in different categories were generally not significant ( $\mathrm{P}>0.05$ ), the major exceptions being the correlation of shear force with crude protein, and with meat redness and yellowness, and of meat lightness and redness with crude protein and fat. 

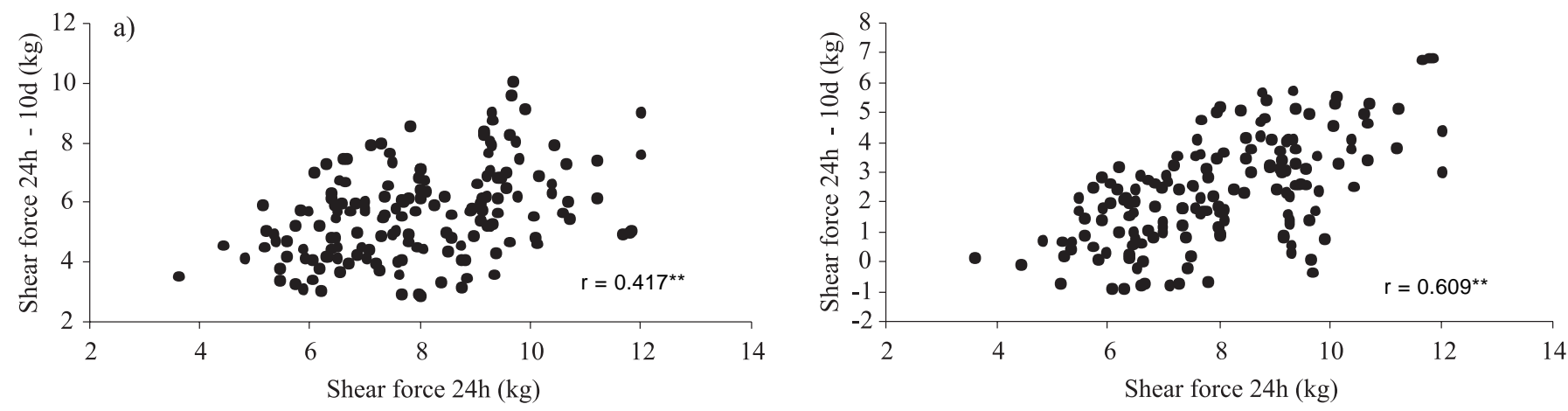

** Significant at the $1 \%$ level $(\mathrm{P}<0.01)$.

Figure 1 - Relationship between shear force in fresh meat (24 hours post mortem) and: a) shear force after ageing (10 days post mortem); b) difference in shear force in fresh and aged meat.

Table 3 - Correlations between physico-chemical characteristics of the $M$. longissimus thoracis in commercial Brazilian beef 1

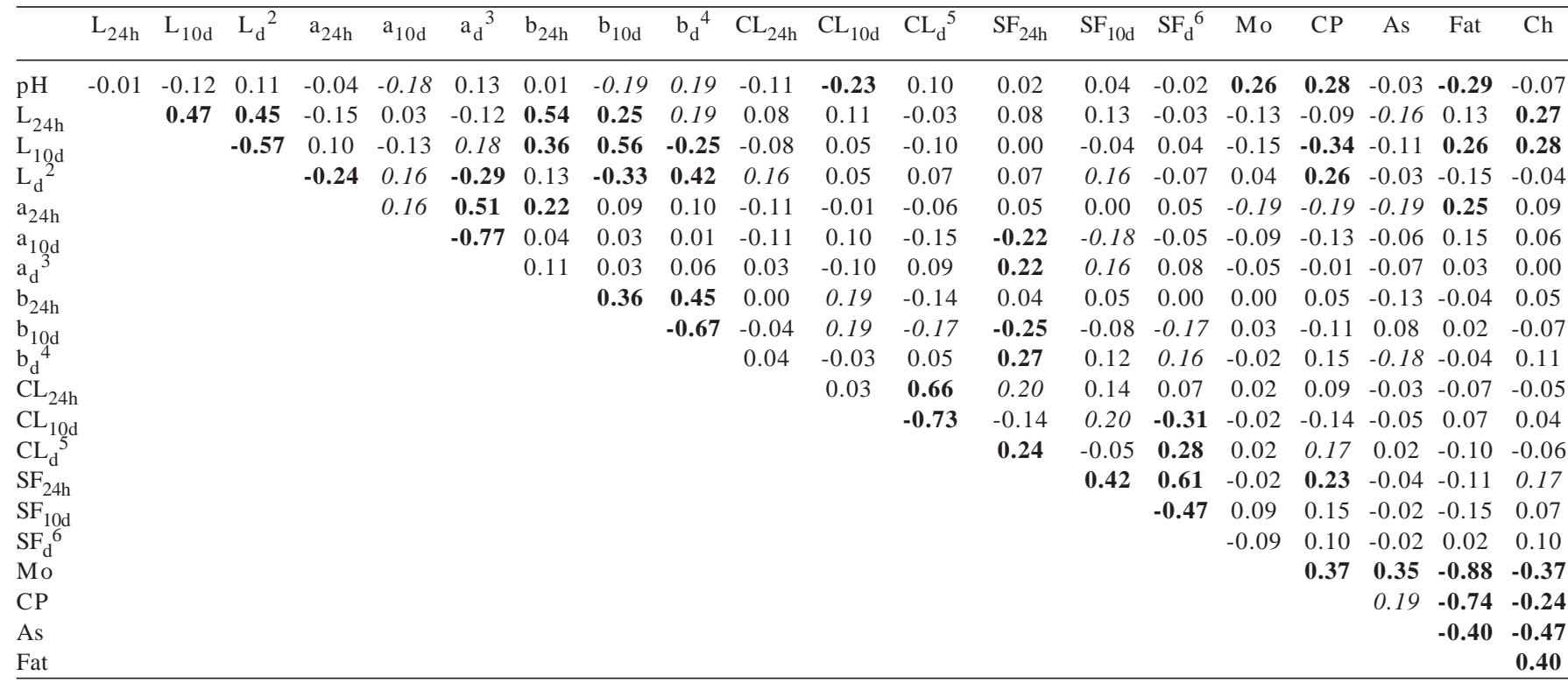

${ }^{1}$ Significant correlations are in italic $(\mathrm{P}<0.05)$ and in bold $(\mathrm{P}<0.01)$.

${ }^{2} \mathrm{~L}_{\mathrm{d}}=$ difference in lightness ( $\mathrm{L}^{*}$ ) between fresh ( 24 hours post mortem) and aged (10 days post mortem) meat.

$3 \mathrm{a}_{\mathrm{d}}=$ difference in redness $\left(\mathrm{a}^{*}\right)$ between fresh ( 24 hours post mortem) and aged (10 days post mortem) meat.

${ }^{4} \mathrm{~b}_{\mathrm{d}}=$ difference in yellowness ( $\left.\mathrm{b}^{*}\right)$ between fresh (24 hours post mortem) and aged (10 days post mortem) meat.

${ }^{5} \mathrm{CL}_{\mathrm{d}}=$ difference in cooking loss (CL) between fresh (24 hours post mortem) and aged (10 days post mortem) meat.

${ }^{6} \mathrm{SF}_{\mathrm{d}}=$ difference in shear force (SF) between fresh (24 hours post mortem) and aged (10 days post mortem) meat.

$\mathrm{Mo}=$ moisture; $\mathrm{CP}=$ crude protein; $\mathrm{As}=\mathrm{ash} ; \mathrm{Ch}=$ cholesterol.

Overall, commercial B. indicus e B. taurus cattle sampled from typical finishing systems practiced in Brazil produced meat with: (a) pH means from 5.82 to 5.92, values above the range considered adequate $(\mathrm{pH}<5.8)$ for shelf-life maintenance (Mach et al., 2008); (b) means of L*, a* and b* color coordinates from 30.9 to 34.7, 16.5 to 20.3 and 3.9 to 5.7, respectively, which are considered within the normal range (38.51 > L* > 29.68, 29.27 > a* > 14.83, and 8.28 > b* > 3.40) by Abularach et al. (1998), (c) shear force means ranging from 7.4 to $8.8 \mathrm{~kg}$ in fresh samples and 5.4 to $5.8 \mathrm{~kg}$ in aged samples, which, for the fresh samples, are considered between moderately tender $(<11.0 \mathrm{~kg})$ and tender $(<8.0 \mathrm{~kg})$, according Bickerstaffe et al. (1997), and (d) intramuscular fat in LT with means between 3.0 to $7.7 \%$. Our results for intramuscular fat in pasture-finished animals are within the range found in most European countries, whereas those for grain-finished animals are well above this range and also exceed those found in New Zealand and Argentina, approaching the fat content observed in the Wagyu breed (Garcia et al., 2008; Purchas \& Zou, 2008).

When compared with FP, samples from FG animals had a much higher fat content (nearly 2.5 times higher), but lower moisture, crude protein and ash. Compared to pasture, the high energy of the grain-based diet determines a higher energy intake in FG animals, resulting in their higher meat fat content, which is in agreement with previous results 
(French et al., 2001, Bruce et al., 2004, Realini et al., 2004). Fat content has been shown to be associated with meat quality traits, such as color (Mancini \& Hunt, 2005), cooking loss and shear force (Bruce et al., 2004). In this study, fat was moderately correlated (Table 3$)$ with $\mathrm{pH}(\mathrm{r}=-0.29)$, meat lightness after ageing $(r=0.26)$, and redness in fresh samples $(r=0.25)$. Overall, animals receiving a higher energy diet are expected to produce meat with a higher fat content and increased glycogen reserves before slaughter, resulting in a lower final pH of meat (Muchenje et al., 2009). Furthermore, as fat content increases, the lighter color of fat may result in an increase in meat lightness, and the amount of oxygen-reactive myoglobin is also expected to increase, thus intensifying the redness of meat (Mancini \& Hunt, 2005).

Differences between the B. taurus and B. indicus groups were not significant for meat moisture and crude protein, but fat content was higher in $B$. indicus by about $0.70 \%$. This result is in agreement with Moreira et al. (2003), who reported higher levels of intramuscular fat in Nelore cattle, when compared with $B$. indicus* $B$. taurus crosses, but it is in contrast with reports by Crouse et al. (1989) and Wheeler et al. (1994), who found lower levels of fat or decreased marbling in $B$. indicus breeds and crosses. On the other hand, Whipple et al. (1990), O’Connor et al. (1997), Gonzalez et al. (2003) and Heinemann et al. (2003) did not find differences in marbling or intramuscular fat when comparing B. taurus, B. indicus and B. taurus*B. indicus. The results of this work indicate that, although finishing system has a major effect on meat fat content, genetic groups still have some influence, with leaner meat in $B$. taurus cattle. This is somewhat in contrast with the results reported by Crouse et al. (1989) and Wheeler et al. (1994), and could result from differences in fat deposition between the $B$. indicus breeds studied by those authors, which were Brahman and Sahiwal, whereas most of the B. indicus cattle raised in Brazil are of the Nelore, Tabapuã and Guzerá breeds.

For animals finished with grain, the level of cholesterol in meat was about twice as much in B. indicus when compared with $B$. taurus. Nevertheless, when they were finished on pasture, $B$. taurus had a slightly higher cholesterol content than B. indicus. Indeed, B. taurus cattle finished on grain had slightly less cholesterol than when finished in pasture, whereas $B$. indicus showed the opposite pattern. This result was not expected, and could represent a true genotype*environment interaction, reflecting the ability of $B$. indicus cattle to accumulate higher levels of cholesterol in energy-rich finishing diets. Moreira et al. (2003) compared cholesterol levels in Nelore and B. taurus crossed animals finished on pasture, and found lower, though non-significant, levels of cholesterol in Nelore, in agreement with the results of this work. On the other hand, the cholesterol level in meat was positively correlated with fat content in this study $(\mathrm{r}=0.40$; $\mathrm{P}<0.01)$, confirming the findings of Alfaia et al. (2007), who reported that meat with high intramuscular fat also has high cholesterol levels.

Finishing with supplementation resulted in meat with lower $\mathrm{pH}$ at 24 hours (difference of $0.10 \mathrm{pH}$ units relative to FP animals), probably because of the higher availability of glycogen at the time of slaughter (Neath et al., 2007). A lower carcass pH in FG animals has also been reported by other authors, both in B. taurus (Nuernberg et al., 2005) and $B$. indicus (Bruce et al., 2004). In the present study, a small correlation was found between $\mathrm{pH}$ and cooking loss in aged meat $(\mathrm{r}=-0.23 ; \mathrm{P}<0.01)$ but the association of $\mathrm{pH}$ with shear force was not significant, in contrast with the results of Muchenje et al. (2009), who reported strong correlations of $\mathrm{pH}$ with cooking loss $(\mathrm{r}=-0.79)$ and shear force $(\mathrm{r}=-0.58)$. In the data of this work, when analyzed within finishing system (results not shown), the correlations of $\mathrm{pH}$ with shear force in fresh and aged meat were similar $(\mathrm{P}>0.05)$, but the correlations with the change in shear force with ageing were -0.17 $(\mathrm{P}>0.05)$ in FG and 0.29 in FP $(\mathrm{P}<0.05)$. These results indicate that the reduction in shear force with ageing did not depend on $\mathrm{pH}$ in FG animals, whereas higher $\mathrm{pH}$ values were associated with greater reductions in shear force in FP. Beltrán et al. (1997) reported that meat with high final $\mathrm{pH}(>5.8)$ has a lower shear force, due to the higher activity of m-calpain and proteolysis of myofibrillar proteins at higher $\mathrm{pH}$ values, which would explain the relationship found in FP animals. The mean $\mathrm{pH}$ was similar in $B$. indicus and $B$. taurus, suggesting that the higher levels of pre-slaughter stress commonly reported for $B$. indicus (Silveira et al., 2006) do not seem to have a negative impact on meat $\mathrm{pH}$.

In $B$. taurus, lightness of fresh and aged meat was similar in FG and FP animals, whereas in B. indicus, meat was lighter in FG than in $\mathrm{FP}(\mathrm{P}<0.05)$, as commonly observed in Zebu cattle (Bruce et al., 2004). This pattern in B. indicus could be a consequence of their higher fat content, especially in FG, and it is confirmed by the positive correlation ( $\mathrm{r}=0.26$, $\mathrm{P}<0.01$ ) between fat content and 24 -hour $\mathrm{L}^{*}$. It is interesting to observe in the results of this work that ageing caused meat to become significantly lighter in FG animals of both genetic groups, whereas in FP, the increase in lightness was non-significant in $B$. taurus and meat became darker with ageing in $B$. indicus. Possibly, the differences observed between treatments for lightness in fresh and aged meat may be attributed to differences in redox pigment stability due to oxidation (Mancini \& Hunt, 2005). Lower color stability is associated with higher rates of poly-unsaturated 
fatty acids (PUFA) and with secondary products of fat oxidation (Alderton et al., 2003). Typically, animals finished on pasture, when compared with those finished with grain, show higher amounts of PUFA (Wood et al., 2008). On the other hand, when B. taurus and B. indicus are compared, higher percentages of PUFA are found in $B$. indicus, both in intramuscular (Bressan et al., 2011) and subcutaneous (Huerta-Leidenz et al., 1993) fat. As PUFAs are of dietary origin and suffer extensive biohydrogenation, the higher deposition found in the meat of $B$. indicus was attributed to a decreased effectiveness in the biohydrogenation process (Bressan et al., 2011), possibly due to morphological and physiological differences between $B$. taurus and $B$. indicus.

Meat redness was significantly lower in FP in fresh meat, and ageing resulted in a similar decline in meat redness in both finishing systems. Differences in redness may be due to the stability of heme pigments (Faustman et al., 1999; Lynch \& Faustman, 2000; Mancini \& Hunt, 2005), and animals finished on pasture usually have higher amounts of poly-unsaturated fatty acids, which have lower levels of lipid stability (French et al., 2000, Descalzo et al., 2005). Therefore, animals from FP would be expected to have higher levels of oxidation of heme pigments, leading to a more tangible decline in redness with ageing, but this was not observed in our study, possibly because of the higher amount of carotenoids in the diet of FP animals (Dunne et al., 2009), which would contribute to lipid stability and meat color shelf-life. Mean redness of fresh and aged meat was similar for the two genetic groups, and the reduction of redness with ageing was also similar. These results suggest that the decline in the ability to form oxymyoglobin with the ageing of meat (Mancini \& Hunt, 2005) is similar in B. indicus and B. taurus.

Yellowness of fresh meat was higher in B. taurus than in $B$. indicus when animals were finished in pasture, but no differences among genetic groups were observed in grainfinishing. However, in aged meat, yellowness was higher in B. taurus in both finishing systems. Yang et al. (2002) showed that the level of $\beta$-carotene (the major pigment responsible for the yellow color of fat in forage-finished animals) in plasma, muscle and adipose tissues is higher in pasture- than in grain-finished animals, and it increases with longer periods of grazing. Therefore, it can be expected that meat from pasture or forage-fed animals would tend to have higher yellowness (Kerth et al., 2007). However, this pattern was only observed in B. taurus animals, which had higher yellowness when finished on pasture, whereas the opposite was observed in B. indicus, with higher yellowness in grain-finished animals.
Neither finishing system nor genetic group had a significant effect on cooking loss of fresh or aged meat samples. In general, cooking loss did not change much with ageing, except in FG animals, where the difference between cooking loss in fresh and aged meat was significant, with an increase in aged meat. Bruce et al. (2004), comparing LT samples aged for 14 days, found higher losses in grainfinished than in pasture-finished Brahman animals. The cooking losses are associated with the water-holding capacity during application of external forces, such as cutting, heating, grinding or pressing (Zhang et al., 2005). Furthermore, the ability of meat to retain its water depends on ionic strength $(\mathrm{pH})$, as well as on quantity and integrity of protein structure (Muchenje et al., 2009). In this study, the highest change in cooking loss with ageing was observed in FG samples, which were also those with lower mean $\mathrm{pH}$ (with a value closer to the iso-electric point of proteins), lower protein percentage (fewer available points to bind water and other peptide chains) and lower shear force in aged and fresh meat (suggesting an increase in protein degradation). Indeed, our results confirm that cooking loss is associated with $\mathrm{pH}$ $(\mathrm{r}=-0.23$ for $\mathrm{pH}$ with cooking loss 10 days) but the association with shear force was opposite to the expected pattern, with a positive correlation between cooking loss and shear force ( $r=0.20$ for 24-hour CL with 24-hour SF, and $r=0.20$ for 10-day CL with 10-day SF).

The shear force of the LT samples was higher in FP animals, both in fresh and aged meat, even though the difference was reduced by about one-half when aged samples were compared to fresh samples. Nevertheless, the drop in shear force with ageing did not differ significantly among finishing systems. No clear effect of finishing system on meat tenderness in beef has been demonstrated so far, with comparisons of shear force of meat from pasture-finishing versus grain-finishing being either nonsignificant (Bruce et al., 2004), in favour of grain-finishing (Dannenberger et al., 2006) or of pasture-finishing (French et al., 2000, Realini et al., 2004). In our results, the highest shear force in LT from cattle finished on pasture may have been due to increased collagen cross-linking, associated with increased exercise (Purslow, 2005). The decrease in meat toughness with ageing may have been caused by the weakening of myofibrillar protein and intramuscular connective tissue, through the action of endogenous enzymes (Koohmaraie et al., 2002).

The shear force value of LT samples was significantly higher in $B$. indicus, especially in fresh meat, in which the difference to $B$. taurus was nearly $1.4 \mathrm{~kg}$, but this difference was reduced to about $0.7 \mathrm{~kg}$ after ageing. This result indicates that meat tenderness benefits more from ageing 
in $B$. indicus than in $B$. taurus. This result was not expected, because it has been reported that $B$. indicus breeds have increased activity of calpastatin (Shackelford et al., 1991; O’Connor et al., 1997), which inhibits the calpain-induced proteolysis occurring with ageing (Koohmaraie et al., 2002), thus resulting in tougher meat in B. indicus (Wheeler et al., 2001). The results of this work do not support this idea. However, in this work, meat samples were kept frozen for 30 days before the ageing period, which could have affected the activity of the calpain-calpastatin complex. A reduction in calpastatin activity in frozen meat has been reported in cattle (Koohmaraie, 1990) and sheep (Duckett et al., 1998), but this pattern has not been confirmed in pigs, where m-calpain, $\mu$-calpain and calpastatin seem to maintain their activity during frozen storage of meat (Kristensen et al., 2006). The reduction in calpastatin activity which is expected to occur in frozen beef could be more pronounced in $B$. indicus cattle, as they have increased calpastatin activity (O’Connor et al., 1997), and this may justify the higher reduction in shear force with ageing which was observed in $B$. indicus animals.

\section{Conclusions}

Finishing with supplementation enhances $\mathrm{pH}$, color and meat tenderness, but causes a large increase in fat content in the two genetic groups evaluated, and in cholesterol content in B. indicus. Large differences are observed among genetic groups in shear force, with better tenderness in B. taurus than in B. indicus. Generally, ageing for 10 days improves the physical characteristics of the meat, including an increase in lightness and in yellowness in most cases, except for B. indicus under pasture-finishing, which has a decline in lightness and maintained yellowness. Meat tenderness improves with ageing in both genetic groups, more pronouncedly in $B$. indicus.

\section{Acknowledgements}

This work was funded by the Brazilian institutions Coordenação de Aperfeiçoamento de Pessoal de Nível Superior (CAPES), Conselho Nacional de Desenvolvimento Científico e Tecnológico (CNPq), Fundação de Amparo à Pesquisa do Estado de Minas Gerais (FAPEMIG), and the Portuguese institutions Instituto Nacional dos Recursos Biológicos (INRB) and Fundação para a Ciência e Tecnologia (FCT). Individual grants to Maria Cristina Bressan (BEX0626/06-6/CAPES), as well as institutional grants to Erika Rodrigues and Lizandra Rossato are acknowledged. The authors wish to thank Gisele Cardoso, and Lisa Botega for technical support, the Federal Inspection Services (Drs. Hugo Verardino and Jorge Luiz Oliveira Afonso), the Minerva and Frisa for facilitating this research.

\section{References}

ABUlARACH, M.L.S.; ROCHA, C.E.; FELÍCIO, P.E Características de qualidade do contrafilé (M. Longissimus dorsi) de touros jovens da raça Nelore. Ciência Tecnologia de Alimentos, v.18, p.205-210, 1998.

ALDERTON, A.L.; FAUSTMAN, C; LIEBLER, D.C. et al. Induction of redox instability of bovine myoglobin by adduction with 4Hydroxy-2-Nonenal. Biochemistry, v.42, p.4398-4405. 2003.

ALFAIA, C.M.M.; CASTRO, M.L.F.; MARTINS, S.V. et al. Effect of slaughter season on fatty acid composition, conjugated linoleic acid isomers and nutritional value of intramuscular fat in Barrosã-PDO veal. Meat Science, v.75, p.44-52, 2007.

AMERICAN MEAT SCIENCE ASSOCIATION - AMSA. Guidelines for cooking and sensory evaluation of meat. Chicago: American Meat Science Association, 1978.

ASSOCIATION OF OFFICIAL ANALYTICAL CHEMISTS. Official methods of analysis. 16.ed. Arlington: AOAC International, 1995. 1025p.

BELTRÁN, J.A.; JAIME, I.; SANTOLARIA, P. et al. Effect of stress-induced high post-mortem $\mathrm{pH}$ on protease activity and tenderness of beef. Meat Science, v.45, p.201-207, 1997.

BICKERSTAFFE, R.; LE COUNTER, C.E.; MORTON, J.D. Consistency of tenderness in New Zealand retail meat. In: INTERNATIONAL CONGRESS OF MEAT SCIENCE AND TECHNOLOGY, 43., 1997, Auckland, New Zealand Proceedings... Auckland: 1997.

BOHAC, C.E.; RHEE, K.S.; CROSS, H.R. et al. Assessment of methodologies for colorimetric cholesterol assay of meats. Journal of Food Science, v.53, p.1642-1645, 1988.

BRAGAGNOLO, N.; RODRIGUEZ-AMAYA, D.B. Determinação de colesterol em carne: comparação de um método colorimétrico e um método por cromatografia líquida de alta eficiência. Revista do Instituto Adolfo Lutz, v.22, p.1-13, 2001.

BRESSAN, M.C.; ROSSATO, L.V.; RODRIGUES, E.C. et al. Genotype $\times$ environment interactions for fatty acid profiles in Bos indicus and Bos taurus finished on pasture or grain. Journal of Animal Science, v.89, p.221-232, 2011.

BRUCE, H.L.; STARK, J.L.; BEILKEN, S.L. The effects of finishing diet and postmortem ageing on the eating quality of the $\mathrm{M}$. longissimus thoracis of electrically stimulated Brahman steer carcasses. Meat Science, v.67, p.261-268, 2004.

CROUSE, J.D.; CUNDIFF, L.V.; KOCH, R.M. et al. Comparisons of Bos indicus and Bos taurus inheritance for carcass beef characteristics and meat palatability. Journal of Animal Science, v.67, p.2661-2668, 1989.

DANNENBERGER, D.; NUERNBERG, K.; NUERNBERG, G. et al. Carcass- and meat quality of pasture $x$ concentrate fed German Simmental and German Holstein bulls. Archiv Tierzucht, v.49, p.315-328, 2006.

DESCALZO, A.M.; INSANI, E.M.; BIOLATTO, A. et al. Influence of pasture or grain-based diets supplemented with vitamin $\mathrm{E}$ on antioxidant/oxidative balance of Argentine beef. Meat Science, v.70, p.35-44, 2005.

DUCKETT, S.K.; KLEIN, T.A.; LECKIE, R.K. et al. Effect of freezing on calpastatin activity and tenderness of callipyge lamb. Journal of Animal Science, v.76, p.1869-1874, 1998.

DUNNE, P.G.; MONAHAN, F.G.; O’MARA, F.P. et al. Review. Colour of bovine subcutaneous adipose tissue: A review of contributory factors, associations with carcass and meat quality and its potential utility in authentication of dietary history. Meat Science, v.81, p.28-45, 2009. 
FAUSTMAN, C.; LIEBLER, D.C.; MCCLURE, T.D. et al. Alpha, betaunsaturated aldehydes accelerate oxymyoglobin oxidation. Journal of Agricultural and Food Chemistry, v.47, p.3140-3144, 1999.

FOLCH, J.; LESS, M.; STANLEY, S.A. simple method for the isolation and purification of total lipids from animal tissues. Journal of Biological Chemistry, v.26, p.497-509, 1957.

FRENCH, P.; O’RIORDAN, E.G.; MONAHAN, F.J. et al. Meat quality of steers finished on autumn grass, grass silage or concentrate-based diets. Meat Science, v.56, p.173-180, 2000.

FRENCH, P.; O’RIORDAN, E.G.; MONAHAN, F.J. et al. The eating quality of meat from steers fed grass and/or concentrates. Meat Science, v.57, p.379-386, 2001.

GARCIA, P.T.; PENSEL, N.A.; SANCHO, A.M. et al. Beef lipids in relation to animal breed and nutrition in Argentina. Meat Science, v.79, p.500-508, 2008.

GONZALEZ, C.B.; PAZO, A.A.; SALITO, V.A. et al. Cattle feeding on pasture. Tenderness differences between Bos indicus, B. taurus and Bos indicus x B. taurus steers. Revista Argentina de Producción Animal, v.23, p.111-118, 2003.

HEINEMANN, R.J.B.; PINTO M.F.; ROMANELLI, P.F. Fatores que influenciam a textura da carne de novilhos Nelore e cruzados Limousin-Nelore. Pesquisa Agropecuária Brasileira, v.38, p.963-971, 2003.

HUERTA-LEIDENZ, N.O.; CROSS, H.R.; SAVELI, J.W. et al. Comparison of the fatty acid composition of subcutaneous adipose tissue from mature Brahman and Hereford cows. Journal of Animal Science, v.71, p.625-630, 1993.

KERTH, C.R.; BRADEN, K.W.; COX, R. et al. Carcass, sensory, fat color, and consumer acceptance characteristics of Angus-cross steers finished on ryegrass (Lolium multiflorum) forage or on a high-concentrate diet. Meat Science, v.75, p.324-331, 2007.

KOOHMARAIE, M. Quantification of Ca2+-dependent protease activities by hydrophobic and ion-exchange chromatography. Journal of Animal Science, v.68, p.659-665, 1990

KOOHMARAIE, M.; KENT, M.P.; SHACKELFORD, S.D. et al. Meat tenderness and muscle growth: is there any relationship? Meat Science, v.62, p.345-352, 2002.

KRISTENSEN, L.; CHRISTENSEN, M.; ERTBJERG, P. Activities of calpastatin, ì-calpain and m-calpain are stable during frozen storage of meat. Meat Science, v.72, p.116-120, 2006.

LOPES, M.A.; MAGALHÃES, G.P. Profitability analysis of finishing beef cattle in feedlot conditions: a case study. Arquivo Brasileiro de Medicina Veterinária e Zootecnia, v.57, p.374-379, 2005.

LYNCH, M.P.; FAUSTMAN, C. Effect of aldehyde lipid oxidation products on myoglobin. Journal of Agricultural and Food Chemistry, v.48, p.600-604, 2000.

MACH, N.; BACH, A.; VELARDE, A. et al. Association between animal, transportation, slaughterhouse practices, and meat $\mathrm{pH}$ in beef. Meat Science, v.78, p.232-238, 2008.

MANCINI, R.A.; HUNT, M.C. Review: current research in meat color. Meat Science, v.71, p.100-121, 2005.

MARIANTE, A.S.; MCMANUS, C.; MENDONÇA, J.F. [2003]. Country report on the state of animal genetic resources: Brazil. Available at: <http://www.fao.org/docrep/fao/010/ a1250e/annexes/CountryReports/Brazil.pdf>. Accessed on: May $16^{\text {th }} 2009$.

MOREIRA, F.B.; SOUZA, N.E.; MATSUSHITA, M. et al. Evaluation of carcass characteristics and meat chemical composition of Bos indicus and Bos indicus x Bos taurus crossbred steers finished in pasture systems. Brazilian Archives of Biology and Technology, v.46, p.609-616, 2003.
MUCHENJE, V.; DZAMA, K.; CHIMONYO, M. et al. Some biochemical aspects pertaining to beef eating quality and consumer health: a review. Food Chemistry, v.112, p.279-289, 2009.

NEATH, K.E.; DEL BARRIO, A.N.; LAPITAN, R.M. et al. Difference in tenderness and $\mathrm{pH}$ decline between water buffalo meat and beef during postmortem aging. Meat Science, v.75, p.499-505, 2007

NUERNBERG, K.; DANNENBERGER, D.; NUERNBERG, G. et al. Effect of a grass-based and a concentrate feeding system on meat quality characteristics and fatty acid composition of longissimus muscle in different cattle breeds. Livestock Production Science, v.94, p.137-147, 2005.

O'CONNOR, S.F.; TATUM, J.D.; WULF, D.M. et al. Genetic effects on beef tenderness in Bos indicus composite and Bos taurus cattle. Journal of Animal Science, v.75, p.1822-1830, 1997.

PURCHAS, R.W.; ZOU, M. Composition and quality differences between the longissimus and infraspinatus muscles for several groups of pasture-finished cattle. Meat Science, v.80, p.470-479, 2008.

PURSLOW, P.P. Intramuscular connective tissue and its role in meat quality. Meat Science, v.70, p.435-447, 2005.

REALINI, C.E.; DUCKETT, S.K.; BRITO, G.W. et al. Effect of pasture vs. concentrate feeding with or without antioxidants on carcass characteristics, fatty acid composition, and quality of Uruguayan beef. Meat Science, v.66, p.567-577, 2004.

SAS Institute, 2004. SAS 9.1.2 for Microsoft Windows. SAS International, Heidelberg, Germany.

SHACKELFORD, S.D.; KOOHMARAIE, M.; MILLER, M.F. et al. An evaluation of tenderness of the longissimus muscle of Angus by Hereford versus Brahman crossbred heifers. Journal of Animal Science, v.69, p.171-177, 1991.

SILVEIRA, I.D.B.; FISCHER, V.; SOARES, G.J.D. Relation between genotype and temperament of grazing steers on meat quality. Revista Brasileira de Zootecnia, v.35, p.519-526, 2006.

SNEDECOR, G.W.; COCHRAN, W.G., 1989. Statistical Methods 8th Edition. Iowa State University Press. Ames, IA. USA.

USDA. [2007]. Agricultural statistics - cattle, hogs and sheep. Available at: <http://www.nass.usda.gov/Publications/Ag_Statistics/ 2007/index.asp>. Accessed on: May $20^{\text {th }} 2008$.

WHEELER, T.L.; CUNDIFF, L.V.; KOCH, R.M. Effect of marbling degree on beef palatability in Bos taurus and Bos indicus cattle. Journal of Animal Science, v.72, p.3145-3151, 1994.

WHEELER, T.L.; CUNDIFF, L.V.; SHACKELFORD, S.D. et al. Characterization of biological types of cattle (Cycle V): carcass traits and longissimus palatability. Journal of Animal Science, v.79, p.1209-1222, 2001.

WHIPPLE, G.; KOOHMARAIE, M.; DIKEMAN, M.E. et al. Evaluation of attributes that affect longissimus muscle tenderness in Bos taurus and Bos indicus cattle. Journal of Animal Science, v.68, p.2716-2728, 1990.

WOOD, J.D.; ENSER, M.; FISHER, A.V. et al. Fat deposition, fatty acid composition and meat quality: a review. Meat Science, v.78, p.343-358, 2008.

YANG, A.; BREWSTER, M.; LANARI, M. et al. Effect of vitamin E supplementation on alpha-tocopherol and â-carotene concentrations in tissues from pasture- and grain-fed cattle. Meat Science, v.60, p.35-40, 2002.

ZHANG, S.X.; FAROUK, M.M.; YOUNG, O.A. et al. Functional stability of frozen normal and high $\mathrm{pH}$ beef. Meat Science, v.69, p.765-772, 2005. 